\title{
Natural and anthropogenic driving forces as key elements in the Lower Danube Basin- South-Eastern Carpathians-North-Western Black Sea coast area lakes: a broken stepping stones for fish in a climatic change scenario?
}

\author{
Doru Bănăduc ${ }^{1^{*}+} \circledast$, Michael Joy ${ }^{2}$, Horea Olosutean $^{3}$, Sergey Afanasyev ${ }^{4}$ and Angela Curtean-Bănăduc ${ }^{3 \dagger}$
}

\begin{abstract}
Background: Climate changes influence the ecosystems and induce potential risks regarding the natural products and services; the human society should predict and adapt in time to these coming global challenges. This research highlights a possible fragmentation of some of the Lower Danube River Basin lentic ecosystems fish populations in a climate change scenario.

Results: The studied climate change potential events will affect 18 fish species of economic interest and eight of conservation interest and will induce disorder in some of the Lower Danube specific type of fish communities. The studied area was identified as a significant hot spot regarding the fish fauna ecological status major hazard, in a possible climate change (heating-drought-water depth decreasing) sequence of potential future events. Primarily the southern lakes of the studied area can be negatively influenced by the decreasing of the lakes water quality and quantity, some of the spawning habitats will vanish, some habitats and species will disappear, suspended sediment and nutrient levels in water will increase, eutrophication phenomenon will increase, the hydrological connectivity will diminish, fish associations' structure will significantly change, etc.

Conclusions: The climate changes trend in the Lower Danube Basin will affect the studied lakes ecological state and associated fish communities; mitigating measures are urgently needed. The future potential relative isolation of researched lakes by the surrounding hydrographical nets, for safety reasons of human communities or to convert inland areas should be banned specially for the lakes: Balta Domnească, Razelm, Tăbăcărie, Siutghiol, Taşaul, Tatlageac, Sinoe, Potcoava, Snagov, Comana, Victoria Gheormane, Dunărea Veche, Oltina, and Bugeac. Some of the researched lakes should be managed as wetlands of international importance and as important stepping stone areas for the fish fauna of the Danube Basin: Snagov, Comana, Victoria Gheormane, Dunărea Veche, Oltina, and Bugeac.
\end{abstract}

Keywords: Global changes, Fish of conservation and economic interest, Alien species, Communities

*Correspondence: ad.banaduc@yahoo.com

†Doru Bănăduc and Angela Curtean-Bănăduc contributed equally to this work

1 "Lucian Blaga" University of Sibiu, Faculty of Science, Dr. I. Rațiu Street 5-7, 550012 Sibiu, Romania

Full list of author information is available at the end of the article

\section{Background}

Globally, researchers and the public are aware of climate change-related events especially rising temperature [1]. For fish, temperature influences all biochemical, physiological, and life history processes [2,3], and as their physiologies are optimized over a relatively narrow range of temperatures [4], thermal conditions control their 
species-specific limits for survival, growth, and reproduction [5]. Thus, discerning and anticipating the effects of climate change are now key research parameters from a fish-related nature-science perspective [6-8]. Climate change predictions for Europe are clear in that air temperatures will rise because of the impact of human activities on the atmosphere $[9,10]$. The predictions are also clear that the current precipitation regime will be altered and will fluctuate from one area to another beyond the normal known seasonal patterns, including that drought episodes will become accentuated [11]. Even extreme climatic events are expected [12]. The Lower Danube Basin played along the geological time a major turning plate role for the trans-continental Danube-Black Sea geoecosystem [13], this hot spot area can be of major interest in revealing early warning information for potential ecological trends, especially in climate change scenarios.

Here we question and investigate whether the synergic effects of human-induced climate change put intensive pressure on our study aquatic habitats and induce environmental risk on some of their associated biodiversity. Furthermore, we study whether the potential for more sudden and extreme effects of climate change could be managed and whether such changes will give future options for stakeholders.

Fish are key elements of aquatic ecosystems and are key components of ecosystem services in both quantitative and qualitative aspects, through the high number of taxa and their variety of ecological needs and adaptations [14-16], thus they are of high value to humankind [17-19]. The European fish fauna including Romanian fish are already found in various red lists, under different degrees of protection [20-25]. However, this classification is not enough for their protection if the associated data detailing the driving forces influencing the structure and functions of fish communities are not quantified and considered, because without this the future impacts cannot be predicted. This is crucial as climate changeinduced impacts on aquatic ecosystems will become strong drivers of fish species vulnerability and distribution in our study area and globally.

Climate change and with it our fish resources can be viewed as humankinds' current inadvertent global experiment $[26,27]$. The hydrological processes which determine the status of fish habitats mainly govern habitat features [28], and these are modified by humans and induced changes of which climate is a significant element [29]. Consequently, the changed ecological characteristics influence the environmental drivers and therefore, impact a variety of fish species [30]. However, one shortcoming of fish response studies in relation to altered climate is that they rarely consider lakes that have important biogeographic connections among different watersheds, and that these connections may be impacted by climate change and can induce potential biogeographic fragmentation.

Long-term connectivity among lakes is a key factor in fish metacommunity distribution, abundance and interactions, due to the influences of connectivity on dispersal and colonization rates [31]. Natural barriers like seawater (i.e., Black Sea) and mountains ranges (i.e., Carpathians) have controlled fish speciation and adaptation over long time periods [13, 32-34]. These historical natural barriers had long-term effects, but relatively fast recent changes brought about by human impacts and climate change can induce new stressors that could break down the continuity of natural stepping stones that lakes are in the study area, as fish will have insufficient time to adapt.

Already there is evidence appearing of fish community changes because of recent glaciations retrogressione.g., the recent remains of the lentic fish species populations in the upper sections of the Carpathian tributaries of Danube [35]. Another example was the analysis of likely scenarios of the Upper-Tisa Lake breakthrough in the Middle Pleistocene [36] that enabled the elucidation of habitats of the Rutilus virgo (Heckel 1852) in Ukraine water bodies, which genetically belong to the water area of the ancient Pannonian lake-sea. It is likely they avoided effects of the catastrophic flooding after the breakthrough [37, 38].

Long-term datasets from commercial fisheries provide indication of shifts in the ecological character of lakes in the Lower Danube area [39], and create potential for assessing impacts on sensitive aquatic ecosystems to environmental supplementary stress.

The lower area of Europe's second biggest waterway, the Danube River, is an example of one of the most both naturally and anthropogenically altered complex convergence hydrographic and zoogeographic areas in Europe [40-44]. Given that in the Lower Danube Basin area 34 fish species have been listed as locally extinct in one century [13, 19, 32, 45-48], it could be an important example for the identification of potential trends in environmental-related changes to fish, including climate change impacts.

Identification of some groups of similar fish communities and lakes in the Lower Danube region can reveal some of the impacts of climate change and other human influences, and potentially offer management opportunities for avoiding the isolation of fish populations, and declines in genetic diversity, through appropriate future conservation strategies.

This study's new hypothesis is that due to their relatively isolated position in the regional hydrographical networks, the studied lakes represent with all their natural history, potential stepping stones for some of the fish 
species allowing spreading, by avoiding major relief geography such as highland areas and seas. New ecological barriers may appear because of human impact including climate change. Understanding the extent of the changes to fish movements and how and where the studied lakes will act as habitats and refugia given the convergencedivergence potential under the predicted climate change scenarios, will be crucial in attempting to diminish a potential fish diversity decreasing or collapse.

This paper's qualitative and quantitative aspects of scientific approach is rather a rare one in the investigated Danube Basin area, in terms of the complexity of analyzed physical, chemical, biological, and ecological data, integrated approach, and obtained results.

In summary, the main aim of this research is to identify potential responses of fish communities to future climate impacts by identifying through an integrated fish community analysis, the sensitivity of different lake fish communities, to the changes likely to occur because of climate change.

\section{Materials and methods}

All the physico-chemical data were obtained in the field in 2018-2020. The biological material was sampled with nets and released immediately after identification in the habitats of origin in the same period. The fish communities of 22 lakes were assessed (Fig. 1), of 34 species
(Table 1) they consisted, respectively: of main economic interest [49] (important species for the local/regional human economy), of secondary economic interest [49] (trophic resource for the species of main economic interest) of conservation interest [49] and alien species.

The 22 studied lakes (Snagov, Balta Comana, VictoriaGheormane, Dunărea Veche, Balta Tarova, Balta Lată, Nuntași, Balta Domnească, Razelm, Tăbăcărie, Siutghiol, Tașaul, Tatlageac, Oltina, Bugeac, Sinoe, Lacul Știucilor, Balta Potcoava, Bălțile Siretului, Turbăria Dersca, Balta Teiva Vișina, and Prutețul Bălătău) belong to the Lower Danube River basin (Fig. 1).

Principal component analysis (PCA) [50] was used to visualize and tease out the similarities between the fish communities. Canonical correspondence analysis (CCA) [51] was applied to reveal the relations between the species, on one hand, and the community structures of each lake, on the other, and the chosen habitat variables. Data standardization was performed on the environmental data by transforming the values in percentages of the highest value. Both PCA and CCA were performed using CANOCO 4.5 [52].

Variation partitioning was performed following the procedure carried out by Karaouazas and Gritzalis [53]. We divided environmental variables into three groups: geographical variables-altitude, latitude, longitude; hydromorphological variables-water depth, lake size;

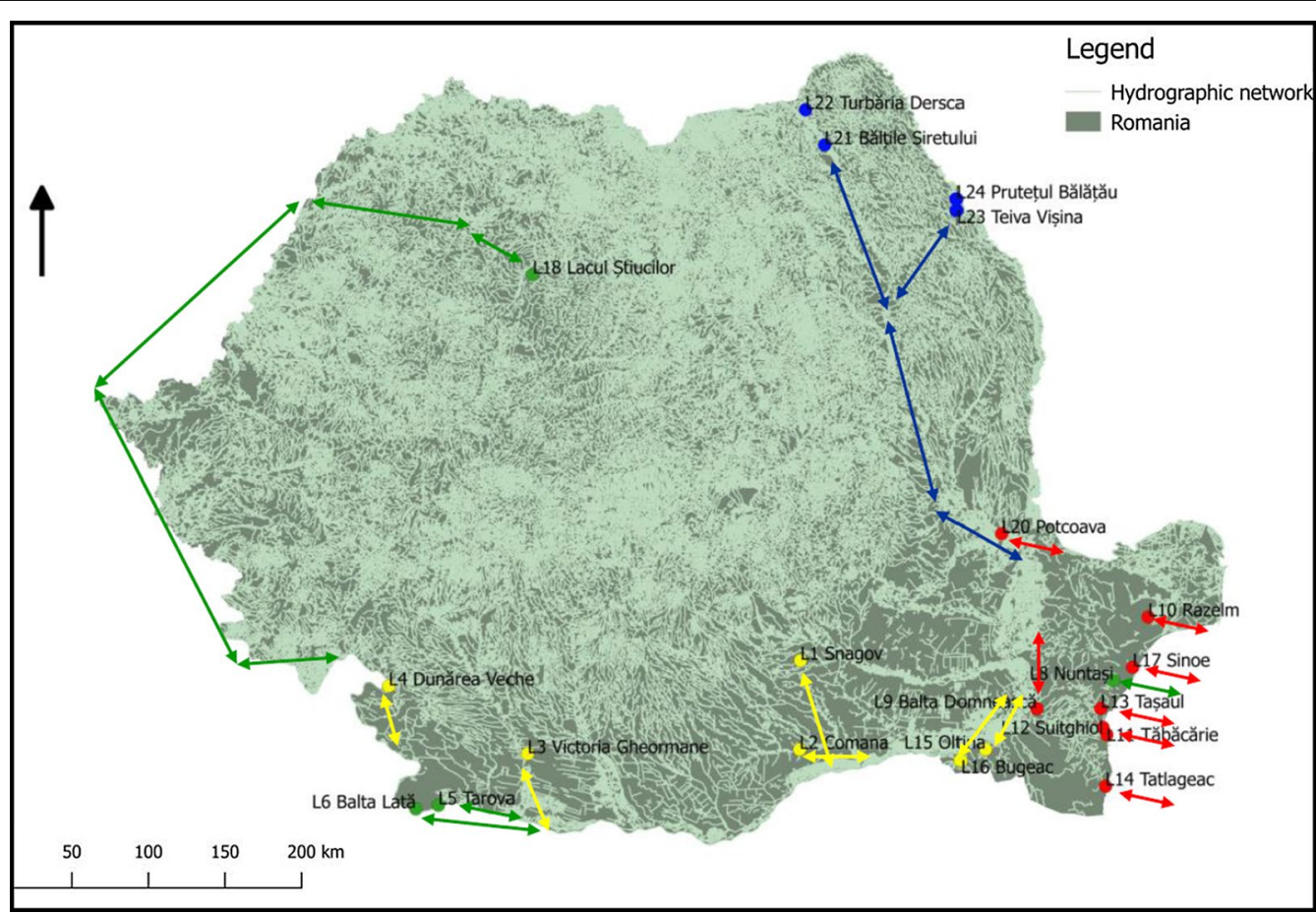

Fig. 1 The 22 lakes with analyzed fish communities, grouped in four categories (base for Fig. 2 analysis): I-red, II-yellow, III-blue and IV-green 
Table 1 The studied fish species

\begin{tabular}{ll}
\hline Main economic interest fish species & \\
\hline Esox lucius & Northern/common pike \\
Tinca tinca & Tench \\
Perca fluviatilis & European perch \\
Rutilus carpathorossicus & Roach \\
Abramis brama & Freshwater bream \\
Cyprinus carpio & Common carp \\
Silurus glanis & Wels catfish \\
Abramis sapa & White-eye bream \\
Aspius aspius & Asp \\
Caspialosa pontica & Pontic shad \\
Hypophthalmichthys molitrix & Silver carp \\
Stizostedion lucioperca & Pike-perch \\
Blicca bjoerkna & White bream \\
Vimba vimba & Vimba bream \\
Ctenopharingodon idella & Grass carp \\
Aristichthys nobilis & Bighead carp \\
Abramis ballerus & Zope \\
Caspialosa nordmanni & Black Sea shad \\
\hline
\end{tabular}

Conservation interest fish species

\begin{tabular}{ll}
\hline Carassius carassius & Crucian carp \\
Rhodeus sericeus & Bitterling \\
Gymnocephalus cernuus & Ruffe \\
Misgurnus fossilis & Weatherfish \\
Cobitis danubialis & Spine loach \\
Leucaspius delineates & Belica \\
Idus idus & Ide \\
Babca gymnotrachelus & Racer goby \\
\hline
\end{tabular}

\begin{tabular}{ll}
\hline Secondary economic interest fish species & \\
\hline Scardinius erythrophthalmus & Rudd \\
Alburnus alburnus & Bleak \\
Gobius sp. & Goby \\
\hline
\end{tabular}

\begin{tabular}{ll}
\hline Alien fish species & \\
\hline Lepomis gibbosus & Pumpkinseed \\
Carassius gibelio & Prussian carp \\
Neogobius fluviatilis & Monkey goby \\
Pseudorasbora parva & Stone moroko \\
Hypophthalmichthys molitrix & Silver carp \\
Perccottus glenii & Chinese sleeper \\
Ctenopharingodon idella & Grass carp \\
Aristichthys nobilis & Bighead carp \\
\hline
\end{tabular}

and eutrophication variables-alkalinity, conductivity, total phosphorus, chlorophyll a. Twelve partial runs of CCA were applied, using fish relative abundance as response variables, and the three groups of environmental variables as explanatory variables, on one hand, or using one of the three environmental groups as explanatory variables and the other two groups together as co-variables. Following the procedure, the sole influence of each environmental variables group as well as the joint effects was extracted from the total explained variation.

\section{Results \\ Lakes' fish communities structure clusters \\ The studied lakes clustering based on fish communities structure}

The PCA analysis $(\lambda 1=0.546 ; \lambda 2=0.201)$ was used based on the long-term monitoring of the fish species relative the abundance data (Fig. 2). The first two axes of the representation explain $74.6 \%$ of the total variation.

The PCA analysis highlighted four fish community biogeographic clusters:

The group I cluster contains eight of the lakes (L9-Balta Domnească; L10-Razelm; L11-Tăbăcărie; L12-Siutghiol; L13-Taşaul; L14-Tatlageac; L17-Sinoe; and L20-Potcoava) and they belong to the extreme dynamic of ichthyofaunal changes over geological time the Lower Danube RiverDanube Delta-North-West Black Sea Coast area [13] (Fig. 2, red).

Cluster II contains six lakes associated with the southern Romanian Carpathians hydrological network that flow into the Danube (L1-Snagov, L2-Comana, L3-Victoria Gheormane; L4-Dunărea Veche; L15-Oltina; L16Bugeac) (Fig. 2, yellow).

Cluster III contains four of the lakes (L21-Bălțile Siretului, L22-Turbăria Dersca, L23-Teiva Vişina, and L24-Prutețul Bălătău) of the northern Moldavian geographic area, between the Romanian Eastern Carpathians and the Siret and Prut rivers, the last significant tributaries of the Danube River before it flows into the Black Sea (Fig. 2, blue).

Cluster IV lakes (L5-Tarova; L6-Balta Lată; L8-Nuntaşi; L18-Lacul Știucilor) are an unnatural lake category in that their fish fauna structure are dominated by the invasive Lepomis gibbosus, and the resistant at low values of oxygen Scardinius erythrophthalmus, these fish species occur mainly in nutrientrich water, and the eurytopic Alburnus alburnus which feeds mainly on plankton a trophic resource dependent on nutrient concentrations (Fig. 2, green);

From a natural and anthropogenic history perspective, the most dynamic Danube Basin ichthyological zone is the Lower Danube River-Danube Delta-NorthWest Black Sea convergence area [13], with the main obstacles the Carpathian Mountains and Iron Gates I and II dams on the Danube [54-58], and diverse human impacts $[59,60]$. The ichthyofaunal characteristics of 


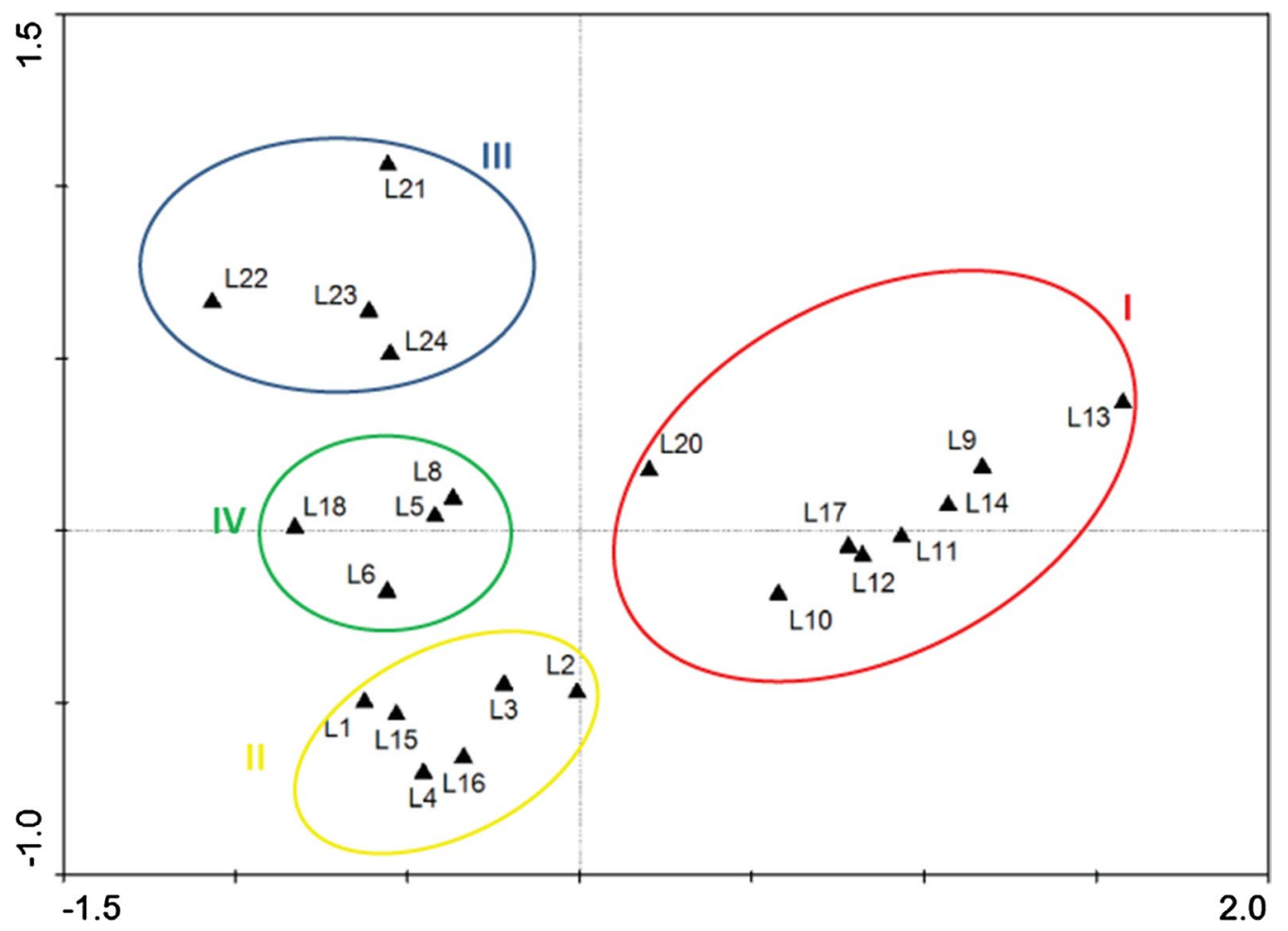

Fig. 2 PCA scatter plot-lakes grouped in four categories based on the fish communities' structure; I-red, II-yellow, III-blue and IV-green

some Danube sub-basins are distinct due to the different geographical characteristics and influences, for example the Tisa, Siret and Prut basins [32, 61]. These lakes represent significant elements which induce/ affect in time the studied fish faunal structure, including the zoogeographic perspective elements [40].

The lake categories I-III, based on fish fauna structure, belong mostly to three well delimited geographical areas characterized by different categories of climatic influences, therefore this influence can be one of the reasons for which the regional fish communities were formed and maintained in the past. Additionally, the possible influence of the presence of specific ichthyofauna clusters; associated with these areas resulting in potentially different sensitivities to potential climate change. The middle-lower Danube hydrographical network habitats contain fish faunas important for this study, as they are under threat from a predicted drier climate [62, 63].

The groups of lakes I and II, under a southern influence, and the associated dominant fish species, are the potential areas under most pressure and threat from a change to a drier climate $[62,64-66]$. The group III is also under threat from drier climate, especially the Eastern Continental excessive influence [65, 67].
Group II has the main stepping stones role for the Danube River basin lentic species needed to avoid basin habitats fragmentation and disconnection. This is especially relevant among the most important lakes in terms of biodiversity and self regulation capacity of Lower Danube River-Danube Delta-North-West Black Sea convergence area and the middle and upper Danube Basin; in the condition in which any way the Lower Danube fish fauna ecological status has a significantly decreasing trend [13].

Group III is important for that sub-basin area of Danube Basin, but can be important too as a stepping stones area between the Danube and eastern Dnister basins. The predicted increase in frequency of catastrophic rain events and consequent floods will make the lakes of this group more vulnerable. There is evidence that the ancient rivers of Transcarpathia ran southward, and then under climate warming the network was reorganized as revealed by the number of terraces of different levels, their morphometric characteristics, and petrographic composition of their sediments' [68]. Currently active bifurcation processes are occurring in the interfluves of the Dnister, Prut and Siret rivers. Thus, according to the Ukrainian Ministry of emergency for the night 17/18 of April 1999, after heavy rainfall near 
to the village of Kostintsy of the Chernivtsy Region a total area $5 \mathrm{~km}^{2}$ of land was displaced. Because of this slip part of catchment area and riverbed of the Bilka Stream of the Siret River basin shifted to the Prut River basin.

The scattered apparently chaotic locations of the lakes in group IV did not reveal any obvious clues as to significant roles as stepping stones in their areas (middle and lower Danube basins), but potential problems with their ecological status.

\section{Lakes' fish species-environment variables clusters}

The CCA performed to link species and associated environmental variables $(\lambda 1=0.453 ; \lambda 2=0.357)$ showed that, from the variables included, lake size was negatively correlated with the first axis $(r=-0.3594)$, depth was positively correlated with the first axis $(r=0.2303)$, and total phosphorus was negatively correlated with the first axis $(r=-0.2005)$. The remaining variables presented consistent correlations with both axes, split into two groups: altitude, latitude and alkalinity, positively correlated with the first axis $(r=0.6553,0.6594$, and 0.5265 , respectively), and negatively correlated with the second axis $(r=-0.2698,-0.5730$, and -0.4114 , respectively); and longitude, conductivity and chlorophyll a, negatively correlated with both the first $(r=-0.5826,-0.3998$, and -0.2319 , respectively) and second axis $(r=-0.5431$, -0.4949 , and -0.1740 , respectively). The first two axes explain $58 \%$ of the total variation.

In general, the geographical variables (altitude and latitude) influence the fish community structure of the lakes group III based on north-eastern geographic location and eastern biogeographical influences: the most northern and high-altitude lakes and close proximity to the neighboring eastern Dniester Basin. This is especially important because of the existence of the confirmed historical connection of the river systems of the Dniester, Tisa, Prut, Suceava and Siret, which created conditions for wide distribution of the Danube fishes. Actual presence of disconnected areas of the Danube endemics (i.e., Hucho hucho, Barbus meridianalis petenyi, Zingel streber, and Gobio uranoscopus) is a consequence of mutual inter-captures of the mentioned river systems [36, 69]. In the same group of geographical variables, latitude is significantly associated with the most northern lake of the group IV.

The hydromorphological variable water depth is associated with the cornerstone cluster group II with potential negative effects on their role as stepping stones between Lower Danube River-Danube Delta-NorthWest Black Sea ichthyologic area and middle and upper Danube basins. The stepping stone lakes include two lakes in group IV with the same general geographical location with the group II. The lakes surfaces variable was identified as being associated with present stress and having relation with the climatic change predicted scenario on the group I, as is one lake in group IV with the same general geographical location, in the well know situations of restraining of wetlands area due to continuous corrections drainages in the lower Danube River including Danube Delta, mostly in the last century [60, 70-72].

The eutrophication related variables (conductivity and chlorophyll a) were revealed as a threat mostly for the most lower Danube Basin lakes of group I. Total phosphorus is associated with I and II lakes groups, plus two of group IV which are in similarly locations.

The CCA (Fig. 3) analysis reveals the two variables directly associated with drought or diminishing water, the depth and surface of aquatic lentic habitats influence the fish communities of groups I and II, and they belong to the most sensitive areas (south and south-east) in terms of climatic changes. It is notable that the lakes (5, 6 and 8) which belong to the group IV, make a common cluster with the groups I and II, underlying all the southern lakes (belonging to different groups of lakes) all particularly sensitive to climate change.

The group I lakes were associated with high conductivity and chlorophyll a values due to these lakes low altitude and thus affected by siltation and pollution of water coming there from all the Danube Basin. The increasing of temperature, decreasing of rainfall, associated loss of vegetation and erosion increasing can advantage the lake fish communities in group I but disadvantage firstly the most important group II, but not only them.

The relationship between alkalinity and the group III lakes is interesting and may be an effect of pollution which altered their chemistry, in the northern Moldavia area where agriculture effects and a lack of water dilution occur [73, 74].

The four lakes in group IV are dominated by the invasive Lepomis gibbosus, and tolerant Scardinius erythrophthalmus fish species and they occur mainly in nutrient-rich water, and Alburnus alburnus which feeds mainly on plankton a trophic resource which is dependent on nutrient concentrations. The altered fish communities in these lakes are possibly due to increasing human impacts, as well as some chaotic intensive fish stocking and restocking in recent decades.

\section{Fish species-environment variables relations}

The environmental variables relate in different ways with all the fish species including the six representative/ indicator species (Fig. 4). Most of fish species, including $66.66 \%$ of representative/indicator fish species (Fig. 4) were associated and can be negatively affected in a heating-drought-climate change scenario by diminishing 


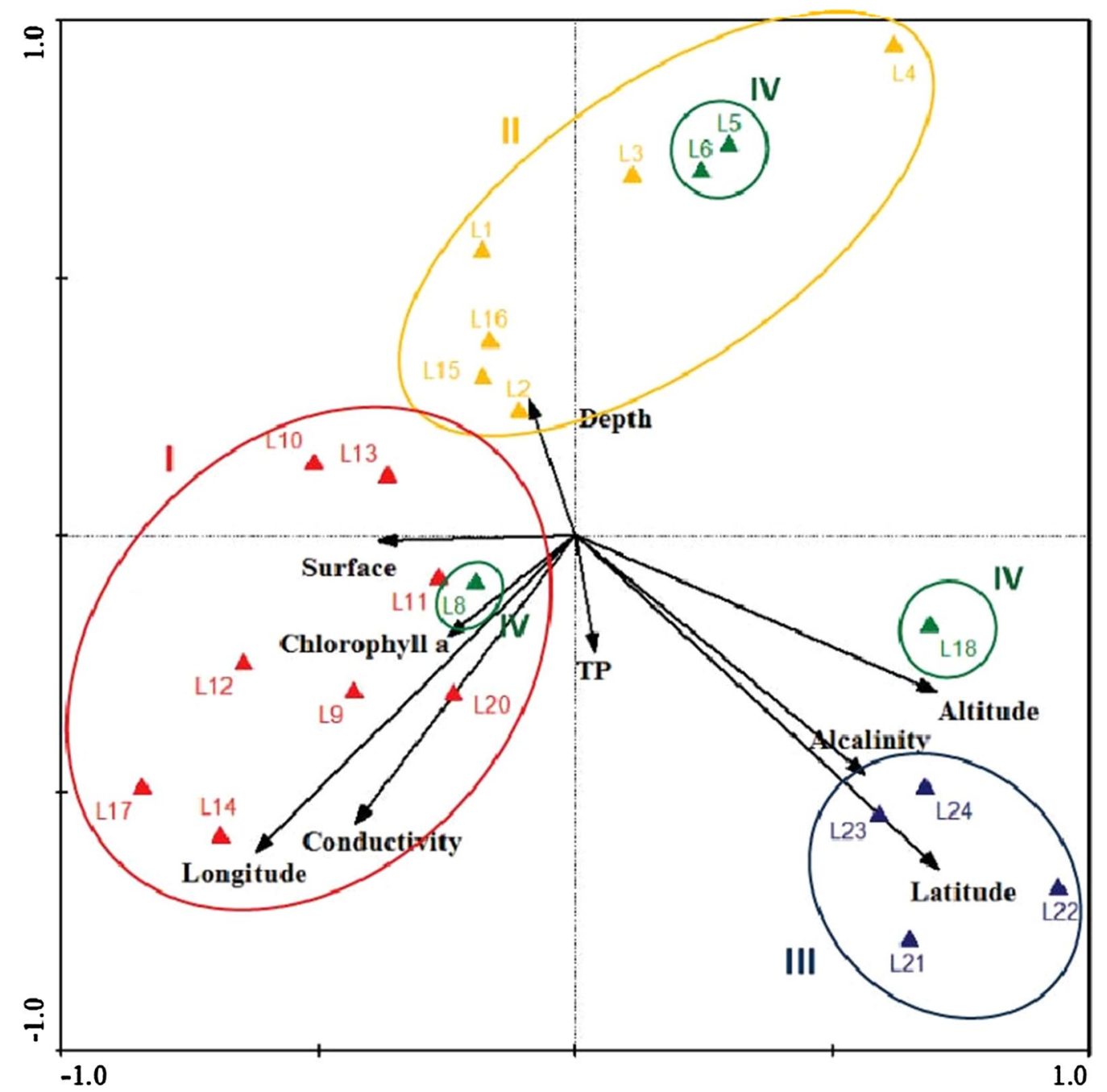

Fig. 3 CCA biplot of samples vs. environmental variables

water depth variable. $16.67 \%$ of representative/indicator fish species (Fig. 4) positively associated with chlorophyll a and conductivity, a possible key explanation of Carassius gibelio success as invasive species in the lower Danube Basin [32], this species will benefit in the situation in which the water will decrease and the sediments density will increase and so the conductivity too, may be the chlorophyll a. $16.67 \%$ of representative/indicator fish species (Fig. 4) is associated with water alkalinity possibly related with water decreasing and increasing the pollutants concentration.

All the fish species were split in four categories of human concern (main economic interest, secondary economic interest-trophic base for the main economic interest fish species, non-native/alien-invasive species, and species of conservation interest. These categories were analyzed in terms of their relationship with different variables and finally with their sensitivity to some climate change scenario (heating-drought).

Among the 18 fish species of main economic interest (Esox lucius, Tinca tinca, Perca fluviatilis, Rutilus carpathorossicus, Abramis brama, Cyprinus carpio, Silurus glanis, Abramis sapa, Aspius aspius, Caspialosa pontica, Hypophthalmichthys molitrix, Stizostedion lucioperca, Blicca bjoerkna, Vimba vimba, Ctenopharingodon idella, Aristichthys nobilis, Abramis ballerus, Caspialosa nordmanni), $\mathbf{8 8 . 8 9 \%}$ are and will be negatively influenced by an increasing temperature-drought climate change scenario, due to diminishing water depth. $75 \%$ of the fish species of conservation interest (Carassius carassius, Rhodeus sericeus, Gymnocephalus cernuus, Misgurnus fossilis, Cobitis danubialis, Leucaspius delineates, Idus idus, Babca gymnotrachelus) will be also negatively affected under this variable dynamic effect. 


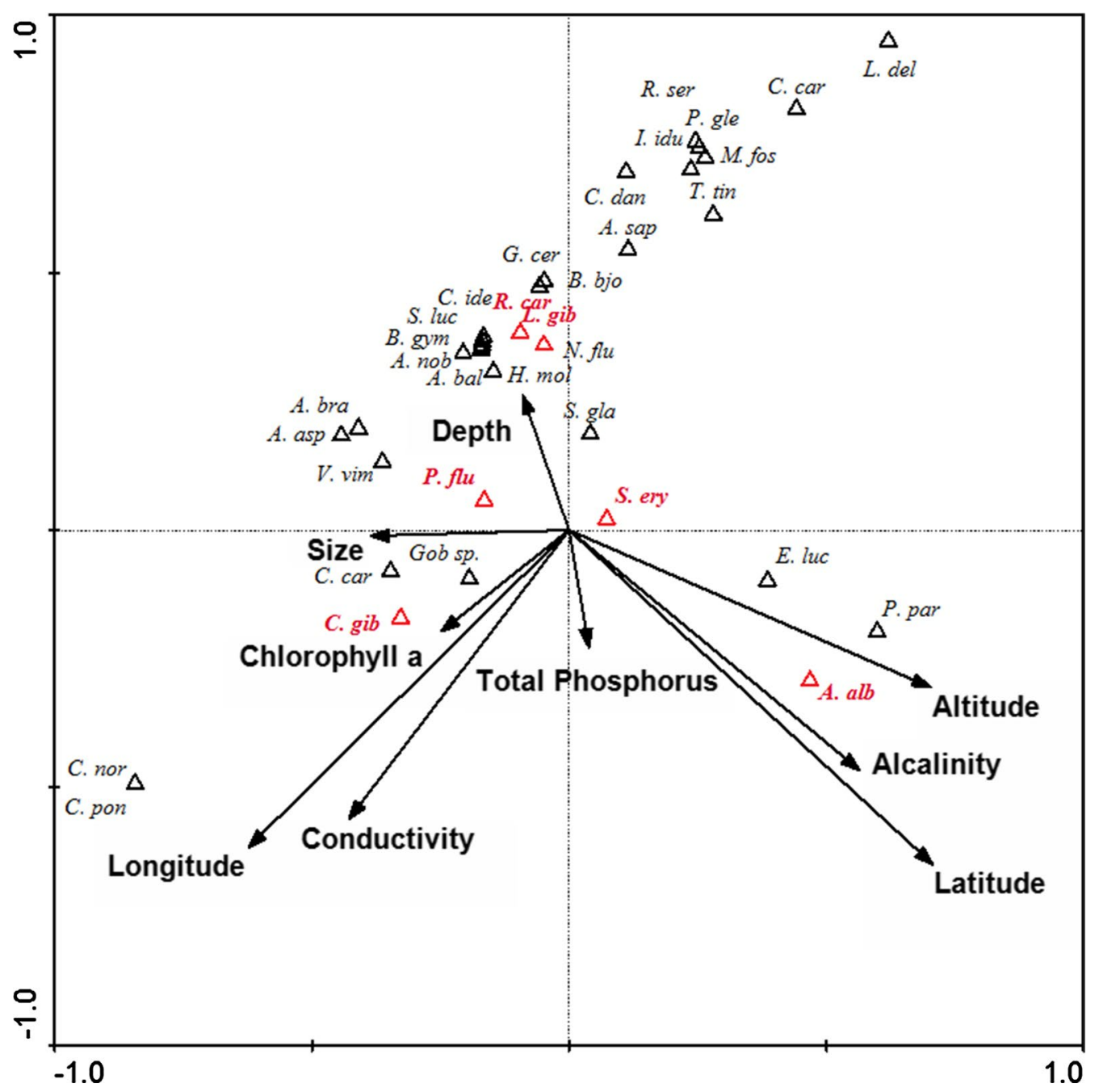

Fig. 4 CCA total species-medium variable

Interesting in terms of valuable-"non-valuable" fish species dynamic, in comparison with the above main economic and conservation interest fish species situation, is the fact that only $\mathbf{3 3 . 3 3 \%}$ of the species of secondary economic interest (Scardinius erythrophthalmus, Alburnus alburnus, Gobius sp.) and also $37.5 \%$ of the alien species (Lepomis gibbosus, Carassius gibelio, Neogobius fluviatilis, Pseudorasbora parva, Hypophthalmichthys molitrix, Perccottus glenii, Ctenopharingodon idella, Aristichthys nobilis), are and can be negatively affected by the approaching climate change scenario.

All these "not so ecologically and/or economically important" fish species will be advantaged by higher temperatures and less depth water bodies in the climate change scenario, in comparison with the ecologically and economically important fish species which will be disadvantaged. No human society economic and ecologic interest in relation with the local and regional fish fauna will be indifferent to a raising temperature-water depth decreasing scenario in the studied categories of lakes.

The fish is a well-known taxonomic group with indication valences in the context of aquatic habitats natural and human-induced variations, including in the climate changes situations [75, 76], valences often used for aquatic ecosystems status and function assessment and monitoring. The studied fish species were grouped in functional/indicative groups, and the relation among these groups and nine environment variables were highlighted (Fig. 4) as is following, the potential trends of lakes habitats and their ichthyocenosis ecological status in a climate change scenario will be also revealed.

The total number of native fish species/native species richness is an attribute of freshwater biotas commonly used in ecological assessment, native species richness 
and abundance are used as opposed to the total species richness, as non-native species generally prefer degraded habitats and thus species richness is considered to reflect the ecologic status of fish communities and of the aquatic ecosystems [77]. Among the analyzed native fish species $8 \%$ are affected by altitude, alkalinity, latitude and total phosphorus; $8 \%$ by chlorophyll a, longitude and conductivity; and by size and depth $84 \%$ (Fig. 4). The climate change scenario will impact the big majority of analyzed native fish species and consequently their lakes ecological status.

The apex predator fish species play a key role in ecosystem stability, are the single fish species with very clear trophic status, and represent both determinant top-down control on ecosystem structure and an indicator for ecosystem health; the number of fish predator species is linked by the variety of biotopes and their states, and the level of dominance reflect the place of this group in the fish community structure $[78,79]$. Under the studied potential climate change effects $80 \%$ of the top predators can be directly affected by aquatic habitats depth and surfaces diminishing in drought conditions and 20\% can be indirectly affected by the water level and surface decreasing due to its sensibility to alkalinity variation due to pollutants concentration increasing in water diminishing conditions (Fig. 4).

Among the European Habitats Directive (92/43EEC) fish species of conservation concern in the considered region [24], five were studied here. $40 \%$ are longitude related due to their ecological bond to the Black Sea area, and also influenced by the water conductivity and chlorophyll $\boldsymbol{a}$ as far as the Danube bring huge quantities of sediments, nutrients and pollutants; $60 \%$ being sensitive to the variation of water bodies depth and size, consequently to the approached drought-water diminishing climate change scenario (Fig. 4).

The fish species entering the lakes from the near lotic systems including the Danube, are based on the past, present, permanent or accidental, direct or indirect connection of these lakes with the surrounding hydrographical nets, including in the flood periods which can be essential for the ecological status of the lakes ecosystems; these species abundance indicate the degree of lakes connectivity with the surrounding hydrographical nets. The fish species which are not considered eurytopic, preferring the flowing water, can be considered as intruders in the studied lakes from the surrounding hydrographic net, as many such species were found in lakes as higher that lakes functional role is as stepping stones in the area. The "intruders" reveal the existence of lakes-surrounding hydrographical net active connections. In the water resource diminishing scenario involving depth and size diminishing $75 \%$ of these intruders fish species will suffer a negative influence, a signal of the actual connections observance and diminishing the role of these lakes as stepping stones for the associated stagnant water and eurytopic fish species. 25\% of the intruders are related with conductivity and chlorophyll $\boldsymbol{a}$ as far as these species are bond with the Black Sea area where the Danube brings huge quantities of sediments, nutrients and

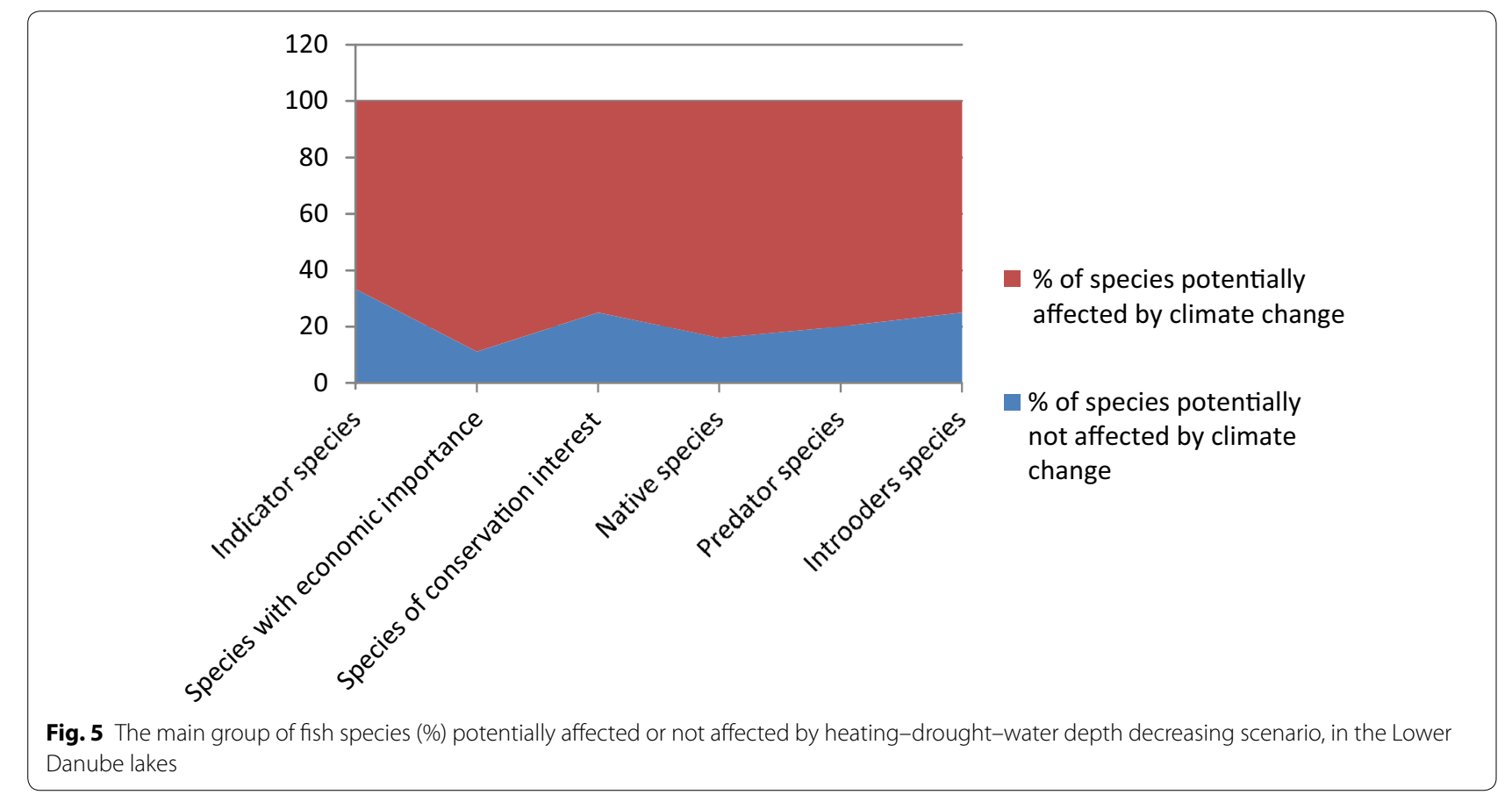


pollutants which influence conductivity and chlorophyll a.

Among the vertebrates, the freshwater fish species have the largest share in the accidental and by-purpose introductions of alien species [80]. The number of nonnative/alien/invasive fish species can reveal direct proportional unbalanced ecological status which follows the increasing number of such species. One of the most fast successful widespread fish in the considered region is Pseudorasbora parva (Temminck and Schlegel 1846) [81], species which will be not affected by a drought climate scenario, but which is affected by altitude, alkalinity and latitude. Interesting is that $75 \%$ of the alien species, of which a half are of economic interest too, will be negatively affected by such a climate change scenario in which water depth and size will be affected (Hypophthalmichthys molitrix, Ctenopharingodon idella, Aristichthys nobilis, Rhodeus sericeus, Lepomis gibbosus, and Perccottus glenii). Carassius gibelio (Bloch, 1782) is affected by water body size and chlorophyll a.

\section{Variance partitioning}

For an in-depth analysis regarding the habitat variables, these were split in three: Geogr.-Geographical variables: altitude, latitude, longitude; Hydro.hydromorphological variables: depth, surface; Eutr.Eutrophication variables: alkalinity, conductivity, total phosphorus, chlorophyll a. Together they explain $81 \%$ of the total variance of the data set.

The equation used is: TEV (total explained variation) $=0.035$ (Hydro and Geo and Eutr) +0.300 (joint Eutr and Geo) -0.010 (joint Eutr and Hydro) +0.006 (joint Hydro and Geo) +0.425 (Eutr) +0.434 $(\mathrm{Geo})+0.207($ Hydro $)=1.397$.

The main influence comes from the geographical variables, which induce $31.06 \%$ of the community variance, and from the eutrophication variables, which induce $30.42 \%$ of the community variance. Even more, the combined influence of geographical variables and eutrophication variables induce an additional $21.47 \%$ of the community variance, leading to the conclusion that the two categories of environmental variables determine $82.95 \%$ of the entire variance, and that hydromorphological variables have a very low influence on the distribution of the fish communities, either as a distinct influence or as co-influences on geographical or eutrophication variables (Table 2).

\section{CCA analyses between environmental variables and fish species}

See Table 3.

\section{Discussion}

Major geographical obstacles (e.g., the Carpathian Mountains and the Black Sea), significant different geographical areas with significant different climate and zoogeographical influences (i.e., Mediterranean, Continental), major/ significant rivers with relatively dense and permanent hydrographical nets basins (i.e., Danube, Tisza, Siret and Prut) and highly dynamic ichthyological zone like the Lower Danube River-Danube Delta-North-West Black Sea convergence area, are the main natural driving forces which clustered along with history the lakes fish fauna of the area studied. The relatively recent human impacts (huge dams on the Danube, pollution, siltation, etc.) as well as the fish fauna management hazards including chaotic stockings created another separate cluster of sites.

The fish fauna had long geological timescales over which had to adapt, and this included lake habitats, which acted as stepping stones. All these lakes which should act like stepping stones are highly important in the conditions of the zoogeographical and ecological importance of a needed hydro-biological trans-continental functional macro-continuum.

The predicted climate change warming and increasing likelihood of droughts, as well as the recent human impacts however, will mean there will be significant pressures placed on fish populations that will threaten and imperil these lakes as optimum habitats for lentic and eurytopic fish species.

Climate change-induced impacts represent a potential break in existing migratory stepping stones especially between the Lower Danube River-Danube Delta-North-West Black Sea area and the middle and upper Danube River areas. This is additional to the already significant negative fragmentation induced by the Iron Gates (I and II) dams and lakes on the Danube.

Furthermore, predicted climate change impacts will also significantly negatively affect the fish species of main economic importance and conservation importance; while having a much less significant impact on the secondary economic important fish species (Fig. 5). What is more, this will likely create a major biological disturbance for the Lower Danube lentic and eurytopic fish communities' types, with obvious ecologic and economic negative effects.

Consequently, there is an urgent need for regional (Lower Danube Basin) management strategies that rely on maintaining/improving proper climate and microclimate characteristics, lentic habitats connectivity, lentic and lotic aquatic habitats natural/semi-natural qualitative and quantitative characteristics preservation, ecologic and economic valuable fish genetic diversity support, and therefore adaptability potential for the target fish populations. 
Table 2 Variation partitioning by partial canonical correspondence analysis (CCA) of fish distribution explained by three groups of environmental variables, geographical (Geo: altitude, latitude, longitude), hydromorphologic (Hydr: depth, surface) and eutrophication (Eutr: alkalinity, conductivity, total phosphorus, chlorophyll a)

\begin{tabular}{|c|c|c|c|c|c|c|}
\hline Run & Responder & Environmental variables & Covariable & \multicolumn{2}{|c|}{ Total inertia } & $\%$ Variation \\
\hline \multicolumn{7}{|c|}{ Total effect: all environmental variables } \\
\hline & Species & All groups & - & 1.397 & & 81.0 \\
\hline Partial effect 1 & Combination & nd Geo and Hydro & & & & \\
\hline 1 & Species & Eutr & Geo and Hydro & 0.425 & 1.397 & 24.64 \\
\hline 2 & Species & Geo and Hydro & - & 0.972 & & 56.36 \\
\hline 3 & Species & Geo and Hydro & Eutr & 0.647 & 1.397 & 37.51 \\
\hline 4 & Species & Eutr & - & 0.750 & & 43.49 \\
\hline \multicolumn{6}{|c|}{ Joint effect: Eutr $\leftrightarrow$ Geo and Hydro $=0.972-0.647=0.750-0.425=0.325$} & 18.84 \\
\hline Partial effect 2 & Combination & nd Eutr and Hydro & & & & \\
\hline 1 & Species & Geo & Eutr and Hydro & 0.434 & 1.396 & 25.18 \\
\hline 2 & Species & Eutr and Hydro & - & 0.962 & & 55.82 \\
\hline 3 & Species & Eutr and Hydro & Geo & 0.622 & 1.397 & 36.06 \\
\hline 4 & Species & Geo & - & 0.775 & & 44.94 \\
\hline \multicolumn{6}{|c|}{ Joint effect: $\mathrm{Geo} \leftrightarrow$ Eutr and Hydro $=0.962-0.622=0.775-0.434=0.340$} & 19.71 \\
\hline Partial effect 3 & \multicolumn{6}{|c|}{ Combination: Hydro and Geo and Eutr } \\
\hline 1 & Species & Hydro & Geo and Eutr & 0.207 & 1.397 & 12.00 \\
\hline 2 & Species & Geo and Eutr & - & 1.190 & & 69.00 \\
\hline 3 & Species & Geo and Eutr & Hydro & 1.159 & 1.397 & 67.20 \\
\hline 4 & Species & Hydro & - & 0.238 & & 13.80 \\
\hline \multicolumn{6}{|c|}{ Joint effect: Hydro $\leftrightarrow$ Geo and Eutr $=1.190-1.159=0.238-0.207=0.031$} & 1.80 \\
\hline
\end{tabular}

The total inertia used here is the sum of all canonical eigenvalues. The sum of all eigenvalues in a correspondence analysis of the species matrix is 1.397 . Thus, the total percentage of the total variation of bug species matrix for each step is: total inertia 100/1.397

Table 3 Results of the CCA analyses between environmental variables and fish species

\begin{tabular}{|c|c|c|c|c|c|}
\hline Axes & 1 & 2 & 3 & 4 & Total inertia \\
\hline Eigenvalues & 0.453 & 0.357 & 0.187 & 0.133 & 2.904 \\
\hline $\begin{array}{l}\text { Species-environment cor- } \\
\text { relations }\end{array}$ & 0.934 & 0.882 & 0.757 & 0.798 & \\
\hline \multicolumn{6}{|c|}{ Cumulative percentage variance } \\
\hline Of species data & 15.6 & 27.9 & 34.4 & 38.9 & \\
\hline $\begin{array}{l}\text { Of species-environment } \\
\text { relation }\end{array}$ & 32.4 & 58.0 & 71.4 & 81.0 & \\
\hline Sum of all eigenvalues & & & & & 2.904 \\
\hline $\begin{array}{l}\text { Sum of all canonical eigen- } \\
\text { values }\end{array}$ & & & & & 1.397 \\
\hline
\end{tabular}

Total inertia is the total variance in species abundance data

The first management actions which should be done to mitigate/avoid the climate changes negative effects on the studied lakes should be made only at the basin level, for coherency in actions and optimum results. Among them we suggest: creation of a permanent complex of integrated monitoring system for the lakes, forestation/ reforestation of the lakes hydrographical basins to stimulate the small local/regional natural water cycles water recirculation, introduction of ecosystem services taxation systems including for the natural water and riverine wood, selective fishing of invasive and not economically or conservation important species, fighting poaching, diminishing/avoiding fragmentation of the lotic systems which connect permanently or seasonally the lakes, reducing pollution, water use rationalization, etc.

The Lower Danube Basin was revealed as being one of the major hot spots in terms of fish fauna status major threats, pressures and risks, this time in a potential climatic change (heating-drought-water depth decreasing) scenario.

The Lower Danube Basin hot spot area identified potential ecological changes trends that can be used also as a pre-alert information area, for potential arrival of similar changes for other surrounding major European and West Asian hydrographic systems like (i.e., Évros, Po, Rhine, Elbe, Oder, Vistula, Dnestr, Bug, Dnepr, etc.).

Even if all or the majority of the fish species of conservation interest were to shift to more appropriate habitats/climate conditions, the relatively unnaturally fast likely changes will strongly affect the ecological equilibrium of lakes locally and regionally, diminish their economic local/regional value and break down the natural 
continuity along the highly important Lower Danube River-Danube Delta-North-West Black Sea and the middle and upper Danube Basin.

Appropriate water resource management actions for the identified vulnerable fish species habitats/lakes, can buffer fish populations climate change-related impacts and associated risks. The worst-case scenario should be to ensure there are at least some potential refuge/ as many as possible of the studied lakes of each of the four identified lake categories, or if not then knots of convergence and divergence of a functional regional hydrographic Danubian River network, in which climate changes conscious conservation managers should be able to optimize conservation and economic objectives by identifying, targeting, and connecting all these lentic habitats as potential fish fauna refugia/areas of convergence-divergence.

The results of this research reveal characteristic categories of lake fish species viability under current and potential future climatic variability of the Lower Danube Basin and provide a robust approach for revealing the trends of fish fauna composition, diversity, ecological status and distribution. We identified the sensitivity to climate change of some lake categories of fish fauna from the perspective of the refugial potential of these habitats. The results of this research have broad implications for the design and future management of the network of Lower Danube lakes.

As a result of climate change, it is likely the southern lakes will likely suffer disturbance through the worsening water quality and quantity, some spawning habitats will be lost, there will be habitat and species loss, increased suspended sediment and nutrient levels in water and eutrophication, diminishing and/or loss of hydrological connectivity, alteration of fish communities structure, and an increase in eurytopic fish species occurrence.

This analysis reveals that there is a relatively large variation in fish community structure throughout the studied lakes categories, and how they might be impacted by climate change:

Isolation of these lakes by the surrounding hydrographical networks, either for safety reasons or to reclaim land should to be forbidden in a future drought scenario mainly for lake groups II and I.

The group II of lakes can be considered as wetlands of international importance and significant needed stepping stone for at least the Danube Basin fish fauna.

The anticipated growth in frequency of catastrophic rainfall episodes and following floods will make the group III of lakes more exposed to fish fauna habitat changes.

The group IV of lakes is due to a complex human impact effects already unbalanced from the point of view of the fish communities and the most sensible to any other supplementary stress, including the climate changes type too.

\section{Conclusions}

The climate changes trend in the Lower Danube Basin will affect the studied lakes ecological state and associated fish communities; mitigating measures are urgently needed.

The future potential relative isolation of researched lakes by the surrounding hydrographical nets, for safety reasons of human communities or to convert inland areas should be banned specially for the lakes: Balta Domnească, Razelm, Tăbăcărie, Siutghiol, Taşaul, Tatlageac, Sinoe, Potcoava, Snagov, Comana, Victoria Gheormane, Dunărea Veche, Oltina, and Bugeac.

Some of the researched lakes should be managed as wetlands of international importance and as important stepping stone areas for the fish fauna of the Danube Basin: Snagov, Comana, Victoria Gheormane, Dunărea Veche, Oltina, and Bugeac.

\section{Abbreviations \\ Geogr:: Geographical variables (altitude, latitude, longitude); Hydro.: Hydro- morphological variables (depth, surface); Eutr.: Eutrophication variables (alkalinity, conductivity, total phosphorus, chlorophyll a).}

\section{Acknowledgements}

Data of this study were obtained and analyzed in the project financed by "Lucian Blaga" University of Sibiu and Hasso Plattner Foundation research Grant LBUS-IRG-2019-05. Data were also obtained and analyzed in the project "Achiziție de servicii pentru stabilirea structurii pe vârste a ihtiofaunei, metric necesar revizuirii metodei de evaluare a stării ecologice a lacurilor pe baza ihtiofaunei. Adaptarea metodei de evaluare bulgară a lacurilor naturale ripariene la lacurile similare din Româniav - contract Administrația Națională Apele Române 57-05.10.2017.

\section{Authors' contributions}

All the authors (DB, MJ, HO, SA, AC-B) contributed to the data analyses and writing of the paper; all the authors have read and agreed to the paper content; DB and AC-B equally contributed to the paper with: paper idea, study concept design, field work, data analyses, writing of the paper. The corresponding author agreed to cover full or in part, the article processing charge. All authors read and approved the final manuscript.

\section{Funding}

The funding institutions were acknowledged.

\section{Availability of data and materials}

Any data related to the paper manuscript are available for any request; the corresponding author can send the requested data.

\section{Ethics approval and consent to participate}

The manuscript is original, has not been published, and is not currently under consideration by another journal!All the authors of the submitted manuscript: respect all the professional and editorial ethic general rules; agree to the terms of Springer Open Licence Agreement. The studied fish were not harmed and released in their natural habitat after identification, after the sampling.

Consent for publication

All the authors of the submitted manuscript consent to participate as co-authors. 


\section{Competing interests}

The authors declare that they have no competing interests.

\section{Author details}

1 "Lucian Blaga" University of Sibiu, Faculty of Science, Dr. I. Rațiu Street 5-7, 550012 Sibiu, Romania. ${ }^{2}$ Institute for Governance and Policy Studies, Victoria University, Wellington 6011, New Zealand. " "Lucian Blaga" University of Sibiu, Applied Ecology Research Center, Dr. I. Rațiu Street 5-7, 550012 Sibiu, Romania. ${ }^{4}$ Institute of Hydrobiology, National Academy of Sciences of Ukraine, Geroiiv Stalingrada 16 Avenue 12, Kiev 21004210, Ukraine.

Received: 17 January 2020 Accepted: 27 April 2020

Published online: 07 May 2020

\section{References}

1. Karl TR, Trenberth KE (2003) Modern global climate change. Science 302(5651):1719-1723

2. Brett JR (1971) Energetic responses of salmon to temperature. A study of some thermal relations in the physiology and freshwater ecology of sockeye salmon (Oncorhynchus nerka). Am Zool 11(1):99-113

3. Fry PEJ (1971) The effect of environmental factors on the physiology of fish. In: Hoar WS, Randall DJ (eds) Fish physiology: environmental relations and behaviour. Academic Press, New York

4. Pörtner HO, Farrell AP (2008) Physiology and climate change. Science 332(5903):690-692

5. Hatton EC, Buckley JD, Fera S, Henry S, Hunt LM, Drake DAR, Johnson TB (2018) Ecological temperature metrics for invasive fishes in Ontario and the Great Lakes Region. Ontario Ministry of Natural Resources and Forestry, Science and Research Branch, Peterborough, ON. Science and Research Information Report IR-15

6. Jentsch A, Kreyling J, Beierkuhnlein C (2007) A new generation of climate change experiments. Front Ecol Environ 5:365-374

7. Mayewski AM, Carleton SD, Birkel D, Dixon AV, Kurbatov E, Korotkikh J, McConnell M, Curran J, Cole-Dai S, Jiang C, Plummer T, Vance KA, Maasch SB, Sneed M, Handley (2017) Ice core and climate reanalysis analogs to predict Antarctic and Southern Hemisphere climate changes. Quat Sci Rev 155:50-66

8. Thuiller W (2007) Biodiversity: climate change and the ecologist. Nature 448:550-552

9. Intergovernmental Panel on Climate Change (IPCC) (2014) Climate change 2014. Synthesis report

10. Kjellström E, Nikulin G, Hanson U, Strandberg G, Ullerstig A (2010) 21 st century changes in the European climate: uncertainties derived from an ensemble of regional climate model simulations. Tellus A 63A:24-40

11. Wong WK, Beldring S (2011) Climate change effects on spatiotemporal patterns of hydroclimatological summer droughts in Norway. J. Hydrometeorol 12:1205-1220

12. Cianfaglione K, Chelli S, Campetella G, Wellstein C, Cervellini M, Ballelli S, Lucarini D, Canullo R, Jentsch A (2018) European grasslands gradient and the resilience to extreme climate events: the SIGNAL Project in Italy. In: Pedrotti F (ed) Climate gradients and biodiversity in mountains of Italy. Geobotany studies (basics, methods and case studies). Springer, Berlin, p 175. https://doi.org/10.1007/978-3-319-67967-9 9

13. Bănăduc D, Rey S, Trichkova T, Lenhardt M, Curtean-Bănăduc A (2016) The Lower Danube River-Danube Delta-North West Black Sea: a pivotal area of major interest for the past, present and future of its fish fauna-a short review. STOTEN 545-546:137-151. https://doi. org/10.1016/j.scitotenv.2015.12.058

14. Holmlund CM, Hammer M (1999) Ecosystem services generated by fish populations. Ecol Econ 29:253-268

15. Lenhardt M, Markovic G, Gacic Z (2009) Decline in the Index of biotic integrity of the fish assemblage as a response to reservoir aging. Water Resour Manage 23:1713-1723

16. Nelson JS (1994) Fishes of the world, 3rd edn. Wiley, New York

17. Giurescu CC (1964) Istoria pescuitului şi a pisciculturii în Romania, Bucureşti

18. Petts GE, Imhof JG, Manny BA, Maher JFB., Weisberg SB (1989) Management of fish populations in large rivers: a review of tools and approaches. In: Dodge DP (ed) Proceedings of the international, Large river symposium (LARS), Canadian Special Publication of Fisheries and Aquatic Science, pp 578-588

19. Schiemer F, Gutti G, Keckeis H, Staraş M (2004) Ecological status and problems of the Danube River and its fish fauna: a review. In: Welcomme R, Petr T (eds) Proceedings of the second symposium on the management of large rivers for fishers, Vol I, FAO Regional Office for Asia and the Pacific, Bangkok, Thailand. RAP Publication 2004/16:273-279

20. Bănărescu PM (1993) Considerations on the threatened freshwater fishes of Europe. Ocrot Nat şi Med Înconj 37(2):87-98

21. Bănărescu PM (1994) The present-day conservation status of the freshwater fish fauna of Romania. Ocrot Nat şi Med Înconj 38(1):1-16

22. Bănărescu PM (2004) Situația actuală a ihtiofaunei de apă dulce a României sub aspect faunistic, taxonomic şi al protecției. Studia Univ VG, SSV Arad 14:43-49

23. Bănărescu PM (2005) Pisces (Pești) 215-260. In: Botnariuc N, Tatole V (eds) Cartea Roșie a vertebratelor din România. Academia Româna, București

24. Bănărescu PM, Bănăduc D (2007) Habitats directive (92/43/EEC) fish species (Osteichthyes) on the Romanian territory. Acta Ichtiol Rom 2:43-78

25. Kottelat M (1977) European freshwater fishes 52. Biologia 52(Supplement 5):1-271

26. Helfman GS (2007) Fish conservation. A guide to understanding and restoring global aquatic biodiversity and fishery resources. Island Press, Washington

27. Ramanathan $V(1988)$ The greenhouse theory of climate change: a test by an inadvertent global experiment. Science 240(4850):293-299

28. Laske S (2017) Surface water connectivity of Arctic lakes drives patterns of fish species richness and composition, and food web structure M. Thesis (Ph.D.) University of Alaska Fairbanks

29. Zhang Y, Sun F, Pan M, Van Niel T, Wegehenkel M (2016) Editorial hydrological processes in changing climate, land use, and cover change. Adv Meteorol. https://doi.org/10.1155/2016/7273424

30. Koenigstein S, Mark FC, Goessling-Reisemann S, Reuter H, Pörtner H-O (2016) Modeling climate change impacts on marine fish populations: process-based integration of ocean warming, acidification and other environmental drivers. Fish Fish 17(4):972-1004

31. Guimarães TFR, Hartz SM, Becker FG (2014) Lake connectivity and fish species richness in southern Brazilian coastal lakes. Hydrobiologia 740:7. https://doi.org/10.1007/s10750-014-1954-x

32. Bănărescu PM (1964) Fauna Republicii Populare Române, PiscesOsteichthyes, XIII. Editura Academiei Române, București

33. Berg LS (1932) Übersicht der verbreitung der Süsswasserfische Europas. Zoogeographica 1:107-208

34. Darlington PJ (1957) Zoogeography. The geographical distribution of animals. Wiley, New York

35. Polishchuk V (1996) Biogeography of continental water bodies of Ukraine and adjacent territories, Holocene complexes. Gidrobiol Zhum 32(N1):325

36. Afanasyev S (2015) Forming of hydrobiota of the river systems in the territory of Ukraine in view of history of hydrographic net. Hydrobiol J 51:3-12

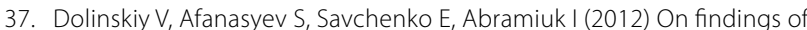
the Pannonian roach Rutilus virgo (Heckel, 1852) (Pisces, Cyprinidae) in waters of Ukraine. Vestn Zool 1:71

38. Dolinskiy V, Afanasyev S, Savchenko E, Abramiuk I, Velykopolskiy I (2012b) Finding of Rutilus virgo (Heckel, 1852) (Pisces, Cyprinidae) in the Ukrainian section of the Upper Tisa basin. In: 39th IAD conference. 21-24 August, 2012, God/Vacrot

39. Năvodaru I, Buijse AD, Staraş M (2002) Effects of hydrology and water quality on the fish community in the Danube Delta Lakes. Int Rev Hydrobiol 87(2-3):329-348

40. Bănărescu PM (1957) Analiza zoogeografică a faunei ihtiologice a Republicii Populare România. Probleme de zoogeografie 5:199-215

41. Bănărescu PM (1970) Some general zoogeographical problems of peripheral and vicarious fishes. Rev Roum Biol Ser Biol Anim 15:315-322

42. Bănărescu PM (1990) Zoogeography of fresh waters, I, General distribution of freshwater animals. Aula-Verlag, Wiesbaden

43. Ujvari I (1959) Hidrografia R.P.Romania. Editura Ştiințifică, Bucureşti

44. Ujvari I (1972) Geografia Apelor României. Editura Ştiințifică, Bucureşti 
45. Antipa G (1909) Fauna ihtiologică a României. Publicațiile Fondului Adamachi, Bucureşti

46. Buşniță T (1960) Modificările ihtiofaunei Dunării de jos în ultimii 100 de ani. Rev Roum Biol 5:4

47. Jankovic D, Krpo J, Lenhardt M, Hegediš A (1994) Ecological characteristics of the Danube fish species. In: Jankovic D, Jovicic M (eds) The Danube in Yugoslavia. Institute for Biological Research, Belgrade, pp 159-173

48. Polačik M, Trichkova T, Vassilev M, Jurajda P (2008) The ichthyofauna of the shoreline zone in the longitudinal profile of the Danube River, Bulgaria. Acta Zool Bulg 60(1):77-88

49. Oțel V (2007) Atlasul peștilor din Rezervația Biosferei Delta Dunării. Editura Centrului de Informare Tehnologică Delta Dunării, Tulcea

50. Pearson K (1901) On lines and planes of closest fit to systems of points in space. Philos Mag 2(6):559-572

51. Ter Braak CJE (1986) Canonical correspondence analysis: a new eigenvector technique for multivariate direct gradient analysis. Ecology 67:1167-1179

52. Ter Braak CJF, Smilauer P (1998) CANOCO reference manual and user's guide to CANOCO for Windows: software for canonical ordination (Version 4). Microcomputer Power, Ithaca (NY)

53. Karaouazas I, Gritzalis KC (2006) Local and regional factors determining aquatic and semi-aquatic bug (Heteroptera) assemblages in rivers and streams of Greece. Hydrobiologia 573:199-212

54. Banu AC (1967) Date geografice şi geologice asupra bazinului şi cursului inferior al Dunării. In: Limnologia sectorului Românesc al Dunării - Studiu monographic. Editura Academiei Române, Bucureşti

55. Buşniță T, Brezeanu T, Oltean M, Popescu-Marinescu V, Prunescu-Arion E, Bănărescu PM, Bogatu D, Gheracopol O, Péterfi LŞ, Vasiliu GA (1970) Monografia zonei Porților de Fier, Studiul hidrobiologic al Dunării şi al afluenților săi. Editura Academiei Republicii Socialiste România, București

56. Gheracopol O, Selim M, Gabriela M (1968) Ichtiofauna Dunării româneşti în portiunea Baziaş (km 1075) - Orşova (km 966) - zona viitorului lac de acumulare Porțile de Fier. Editura Academiei Republicii Socialiste România - Grupul de cercetari complexe Porțile de Fier, București

57. Oancea D, Velcea V (1987) Geografia Romaniei III Carpații şi Depresiunea Transilvaniei. Editura Academiei, Bucureşti

58. Posea G (1964) Defileul Dunării. Natura. Seria Geografie Geol 16:1

59. Curtean-Bănăduc A, Bănăduc D, Bucşa C (2007) Watersheds management (Transylvania, Romania)_implications, risks, solutions. In: Strategies to enhance environmental Security in transition countries, NATO Science for Peace and Security Series C-Environmental Security, Springer, pp 225-238. https://doi.org/10.1007/978-1-4020-5996-4_17

60. Tockner K, Uehlinger U, Robinson CT (2009) Rivers of Europe. Academic Press, Cambridge, p 28

61. Bănărescu PM (1969) Fauna Republicii Populare Române, Cyclostomata şi Chondrichthyes, XII. Editura Academiei Române, Bucureşti

62. Efthymiadis D, Goodess CM, Jones PD (2011) Trends in Mediterranean gridded temperature extremes and large-scale circulation influences. Nat Hazard Earth Syst 11:2199-2214

63. Szinell CS, Bussay A, Szentimrey T (1998) Drought tendencies in Hungary. Int J Climatol 18(13):1479-1491

64. Busuioc A, Dobrinescu A, Bîrsan MV, Dumitrescu A, Orzan A (2015) Spatial and temporal variability of climate extremes in Romania and associated large-scale mechanisms. Int J Climatol 35(7):1278-1300
65. Păltineanu C, Mihăilescu IF, Seceleanu I, Dragotă C, Vasenciuc F (2007) Using aridity indices to describe some climate and soil features in Eastern Europe: a Romanian case study. Theor Appl Climatol 90(3-4):263-274

66. Ștefan S, Ghioca M, Rimbu N, Boroneant C (2004) Study of meteorological and hydrological drought in southern Romania from observational data. Int J Climatol 24(7):871-881

67. Croitoru AE, Minea I (2015) The impact of climate changes on rivers discharge in Eastern Romania. Theor Appl Climatol 120(3-4):563-573

68. Gernechuk KI (1960) Tectonic regularities in orography and river net of the Russian plain. Publ. Hose of Lviv University, Lviv

69. Polischuk VV, Garasecvich IG (1986) Biogeographic aspects of investigations of the water bodies of the Danube River basin within the USSR limits. Naukova Dumka Press, Kyiv

70. Ionuş O, Licurici M, Pătroescu M, Boengiu S (2015) Assessment of floodprone stripes within the Danube drainage area in the South-West Oltenia Development Region, Romania. Nat Hazards 75:969-988

71. Năstase A, Oțel V, Năvodaru I (2017) Ecological status of fish fauna in arms of the Danube Delta (Danube Delta Biosphere Reserve, Romania) at the beginning of the third Millennium. Acta Zool Bulg 69(3):349-360

72. Schwarz $U$ (2010) Assessment of the restoration potential along the Danube and main tributaries, For WWF International Danube-Carpathian Programme, Vienna

73. Rotaru A, Răileanu P (2008) Groundwater contamination from waste storage works. Environ Eng Manage J 7(6):731-735

74. Teodosiu C, Barjoveanu G, Teleman D (2003) Sustainable water resources management 1. River basin management and the EC Water Framework Directive. Environ Eng Manage J 2(4):377-394

75. Lawrence AJ, Hemingway KL (eds) (2003) Effects of pollution on fish. Wiley-Blackwell, Hoboken

76. Mohseni O, Stefan HG, Eaton JG (2003) Global warming and potential changes in fish habitat in US streams. Clim Change 59:389-409

77. Joy M (2015) A fish index of biotic integrity (IBI) for Horizons Regional Council, June 2015, Horizons Report 2015/EXT/1463, Envirolink Report 1541-HZLC1 18, Ecology group Massey University Palmerston North

78. Vejřik L, Vejřiková I, Blabolil P, Eloranta AP, Kočvara L, Peterka J, Sajdlová Z, Chung SHT, Šmejkal M, Kiljunen M, Čech M (2017) European catfish (Silurus glanis) as a freshwater apex predator drives ecosystem via its diet adaptability. Sci Rep-UK 7:1-15

79. Sergio F, Newton I, Marchesi L, Pedrini P (2006) Ecologically justified charisma: preservation of top predators delivers biodiversity conservation. J Appl Ecol 43:1049-1055

80. Holčik J (1991) Fish introductions in Europe with particular reference to its central and eastern part. Can J Fish Aquat Sci 48(Supplement 1):13-23

81. Anastasiu P, Preda C, Bănăduc D, Cogălniceanu D (2017) Alien species of European Union concern in Romania. Transylv Rev Syst Ecol Res 19(3):93-106

\section{Publisher's Note}

Springer Nature remains neutral with regard to jurisdictional claims in published maps and institutional affiliations. 